\title{
10
}

\section{Re-oxygenation Coefficient in QUAL2E: a Prediction Methodology}

\author{
Eduardo Queija de Siqueira and Alan Cavalcanti da Cunha
}

The water quality model QUAL2E has been applied worldwide to modeling dissolved oxygen (DO) and biochemical oxygen demand (BOD) in rivers. The model is an important management tool for environmental impact studies, however a difficulty relating to its application for DO and BOD computations is the quantification of the re-aeration or re-oxygenation coefficient $K_{2}$. The procedure used to establish $K_{2}$ is extremely important if the model is to represent real water stream conditions. A simple methodology for estimating QUAL2E input parameters related to re-aeration coefficient calculations based on open channel hydraulic characteristics is described in this chapter. It aims to give guidelines to professionals and researchers who plan to use QUAL2E. A brief review of the re-aeration process in water streams is briefly reviewed.

\subsection{Modeling and the QUAL2E Model}

Modeling consists of simplifications based on hypotheses about the structure and behaviour of a physical system. Using a model one tries to explain the properties of the system and estimate its response to different stimuli. Through a model it is possible to quantify a river's self-purification capacity and then to foresee the impacts resulting from a waste discharge. This way, the model can indicate the reason why some management alternatives are better than others, thus presenting an important tool for environmental impact studies. According

Queija de Siqueira, E. and A. Cavalcanti da Cunha. 2001. "Re-oxygenation Coefficient in QUAL2E: a Prediction Methodology." Journal of Water Management Modeling R207-10. doi: 10.14796/JWMM.R207-10.

(C) CHI 2001 www.chijournal.org ISSN: 2292-6062 (Formerly in Models and applications to Urban Water Systems. ISBN: 0-9683681-4-X) 
to Thomann and Mueller (1987), surface water quality modeling brings a better knowledge of the mechanisms and interactions that justify various water quality behaviours, and comprises a rational base for decision making on stream water management.

QUAL2E has been developed by researchers world-wide in the last 30 years and has a long history of usage (Bittencourt et al., 1995; Cubillo et al., 1992); Demetracopoulos and Stefan, 1983a; Gastaldini, 1982; Lo and Chen, 1991; Siqueira, 1996; Walton and Webb, 1994). QUAL2E computes the changes of several water components such as DO, coliforms, temperature, nitrogen, phosphorus, conservative and non-conservative components. Barnwell et al., (1989) mention that this model has been mainly applied to dissolved oxygen. QUAL2E has proven to be effective for dissolved oxygen modeling analysis in rivers and contains one of the more sophisticated kinetics of current water quality models (Walton and Webb, 1994). One difficulty related to its application for DO and BOD is the quantification of the re-aeration or reoxygenation coefficient, $K_{2}$.

\subsection{Re-oxygenation and its Quantification}

The process of oxygen exchange between atmosphere and the water stream is called re-aeration or re-oxygenation. Oxygenation is the physical absorption of oxygen from the atmosphere into flowing water. In running waters, reaeration has an extremely important role in maintaining aerobic and facultative aquatic life because it brings in oxygen from the atmosphere in a natural way to the aquatic medium. Currently re-aeration in streams is still being extensively investigated (Qaisi and Thibodeaux, 1997; Thibodeaux et al., 1994; Koh et al., 1995; Moog and Jirka, 1999a; Moog and Jirka, 1999b; Weiss, 1998).

Several models for the quantification of the coefficient $K_{2}$ exist. Rathbun (1977), in a review about re-aeration coefficient in flowing waters, emphasised three measuring techniques: the oxygen balance technique, the disturbed balance technique and the tracer technique. Besides these three methods, Bicudo and James (1989) and Giorgetti (1991) described an indirect method for quantifying the re-aeration coefficient using a soluble probe. Bennett and Rathbun (1972, p.58) concluded that the technique using tracers is better than other techniques used for quantifying the re-aeration coefficient in open channels because it has the advantage of measuring re-aeration independently of other DO sources and sinks in water. Barbosa and Giorgetti (1995) reaffirmed that the most acceptable method is the gaseous tracer technique. However this method requires considerable field and laboratory work, specialised equipment and skilled technicians. 
Although the gaseous tracer technique is the most recommended, from the technical point of view, Rathbun, 1977) indicates that in some studies of water quality modeling no technical or financial conditions are available to perform such field measurements. In this case, the use of predictive equations for $K_{2}$ based on literature is most appropriate.

These equations should be used with caution, realising the experimental conditions in which they were generated. Preferentially, they should be applied in similar hydraulic conditions, being aware of their accuracy and limitations. It is common that these different methods will present quite different results for the same hydraulic conditions.

Moog and Jirka (1999a) mentioned that errors remain large in these equations, pointing to a need for additional investigation. In an evaluation of ten commonly used equations Moog and Jirka (1998) found values of $K_{2}$ in error by a factor of two or greater from measured values in more than half of the cases; many produced five-fold errors in more than $10 \%$ of cases. Moog and Jirka (1999b) also presented a model then still under development which could provide proper scaling for oxygen transfer in small-roughness flows by accounting for the increase in near-surface turbulent energy dissipation rates.

QUAL2E offers eight $K_{2}$ calculation options; six predictive equations from literature and two options for measured values. The six predictive equations for $\mathrm{K}_{2}$ incorporated in the QUAL2E model were analysed by several authors (Bowie et al., 1985; Bennett and Rathbun, 1972; Schultz, 1989) and are listed in Table 10.1. QUAL2E model equations are mostly empirical and semi-empirical equations are proposed for relating $K_{2}$ to measurable flow parameters like velocity and depth. These equations were obtained from regression analysis of field data.

Barbosa (1989) mentions that the semi-empirical formulations have been obtained from a theoretical model for the mass transfer process and that their coefficients were determined by regression analysis of experimental data. Empirical formulae were obtained from dimensional analysis, involving flow and gas-liquid system mean parameters and from regression analysis that determined the equation that best fitted the experimental data. Some equations include factors like Froude Number, friction velocity and others. Formulations include Froude Number $(F r=U / \sqrt{g H})$ in an attempt to consider the wave action effects and other surface disturbances affecting re-aeration. Once the turbulence generated at the bottom of the channel can be seen at the surface level, the friction velocity $\left(u^{*}=\sqrt{g H S}\right)$, in terms of the slope of the energy grade line or channel slope, $S$, is also included in some equations. 
Table 10.1 Predictive equations in small roughness for the re-aeration coefficient, $\mathrm{K}_{2}\left(\right.$ day $^{-1}$ ), in logarithmic base 10 at $20^{\circ} \mathrm{C}$, incorporated in QUAL2E (Siquera, 1996).

\begin{tabular}{|c|c|c|}
\hline Authors & Equations ( SI Units) & Equations (English Syst \\
\hline CHURCHILL et al., (1962) & $5.03 \frac{U^{0,969}}{H^{1,673}}$ & $11.6 \frac{U^{0,969}}{H^{1,673}}$ \\
\hline $\begin{array}{l}\text { LANGBEIN and DURUM } \\
\text { (1967) }\end{array}$ & $5.14 \frac{U}{H^{1,33}}$ & $7.6 \frac{U}{H^{1,33}}$ \\
\hline $\begin{array}{l}\text { O'CONNOR and DOBBINS } \\
(1958)\end{array}$ & $3.93 \frac{U^{0,5}}{H^{1,5}}$ & $12.9 \frac{U^{0,5}}{H^{1,5}}$ \\
\hline OWENS et al., (1964) & $5.34 \frac{U^{0,67}}{H^{1,85}}$ & $21.7 \frac{U^{0,67}}{H^{1,85}}$ \\
\hline $\begin{array}{l}\text { TRACKSTON and KRENKEL } \\
\qquad(1969)\end{array}$ & $\frac{24.9\left(1+F^{0,5}\right) u^{*}}{H}$ & $\frac{24.9\left(1+F^{0,5}\right) u^{*}}{H}$ \\
\hline $\begin{array}{l}\text { TSIVOGLOU and WALLANCE } \\
\qquad(1972)\end{array}$ & $86400 c S U$ & $86400 c S U$ \\
\hline $\begin{array}{l}\mathrm{g}=\text { gravity acceleration, }\left(\mathrm{m} / \mathrm{s}^{2}\right) \\
V=\text { mean velocity in the river stretch, } \\
\quad(\mathrm{ft} / \mathrm{s}) \text { or }(\mathrm{m} / \mathrm{s}) \\
H=\text { mean depth in the river stretch, } \\
\quad(\mathrm{ft}) \text { or }(\mathrm{m}) \\
S=\text { slope in the river stretch, } \\
\quad(\mathrm{ft} / \mathrm{ft}) \text { or }(\mathrm{m} / \mathrm{m}) \\
U^{*}=\text { shear velocity, }(\mathrm{ft} / \mathrm{s}) \text { or }(\mathrm{m} / \mathrm{s}) \\
F=\text { Froude Number, }(\text { dimensionless }) \\
\quad(F r=V / \sqrt{g H}) \\
\mathrm{Q}=\text { flow rate, }\left(\mathrm{ft}^{3} / \mathrm{s}\right) \text { or }\left(\mathrm{m}^{3} / \mathrm{s}\right)\end{array}$ & \multicolumn{2}{|c|}{$\begin{array}{l}\text { Units in English System: } \\
\mathrm{c}=0.054 \mathrm{ft}^{-1} \text { for } 15 \mathrm{ft}^{3} / \mathrm{s} \leq \mathrm{Q} \leq 3000 \mathrm{ft}^{3} / \mathrm{s} \\
\text { Units in International System }(\mathrm{SI}) \text { : } \\
\mathrm{c}=0.177 \mathrm{~m}^{-1} \text { for } 0.42 \mathrm{~m}^{3} / \mathrm{s} \leq \mathrm{Q} \leq 84.96 \mathrm{~m}^{3} / \mathrm{s}\end{array}$} \\
\hline
\end{tabular}

\subsection{Re-oxygenation Coefficient Quantification for the QUAL2E Model, Methodology}

Table 10.1 shows that $K_{2}$ calculation for the QUAL2E model is made from water stream flow characteristics (mean depth, slope and mean velocity). These hydraulic characteristics, however, are indirectly calculated in QUAL2E as a function of flow rate, through two methods: discharge coefficients or Manning coefficient for trapezoidal cross section. 
The user selects the method for computer simulation. According to Barnwell et al. (1989), preference should be given to the discharge coefficient method, since error occurs in the $K_{2}$ calculation resulting from estimating Manning coefficient for a trapezoidal cross section.

For the discharge coefficient method, mean velocities and depths are calculated as a function of the flow rate $(\mathrm{Q})$, using the following equations:

$$
\begin{aligned}
& V=a Q^{b} \\
& H=c Q^{d}
\end{aligned}
$$

where:

$$
\begin{aligned}
H & =\text { depth }(\mathrm{L}) \\
a, b, c, d & =\text { discharge coefficients; } \\
V & =\text { stream mean velocity }\left(\mathrm{LT}^{-1}\right) .
\end{aligned}
$$

Obtaining the necessary data for re-aeration coefficient calculation requires fieldwork followed by computer work. Initially, discharge coefficients $(a, b, c, d)$ for a water stream should be determined using field observations from a river stretch selected for estimating the discharge coefficients. A location with a representative cross section should be determined. At this location flow rates, depth and mean velocity are measured. These measurements should be taken at at least three different times of the year in order to include a considerable variation in the flow rates. This variation should include the flow rates range at the location where the model will be used for computer simulations. The choice of the flow rate measurement method should be made according to local conditions, availability of measuring equipment, human resources and site characteristics.

Data are plotted twice, the first graph showing mean depth versus flow rate and the second, mean velocity versus flow rate, as shown in Figure 10.1. From the graphs, with the support of a regression program, a non-linear adjustment is made in order to determine coefficients $a, b, c$, and $d$ in Equations 10.1 and 10.2. These coefficients are incorporated into the model. The model also requires other data for the re-aeration coefficient calculation, however these are not discussed in this chapter.

When a simulation for a given flow rate condition is desired, flowraterelated velocities and depths are calculated and QUAL2E then calculates the reaeration coefficient, $K_{2}$. 
FIELD WORK

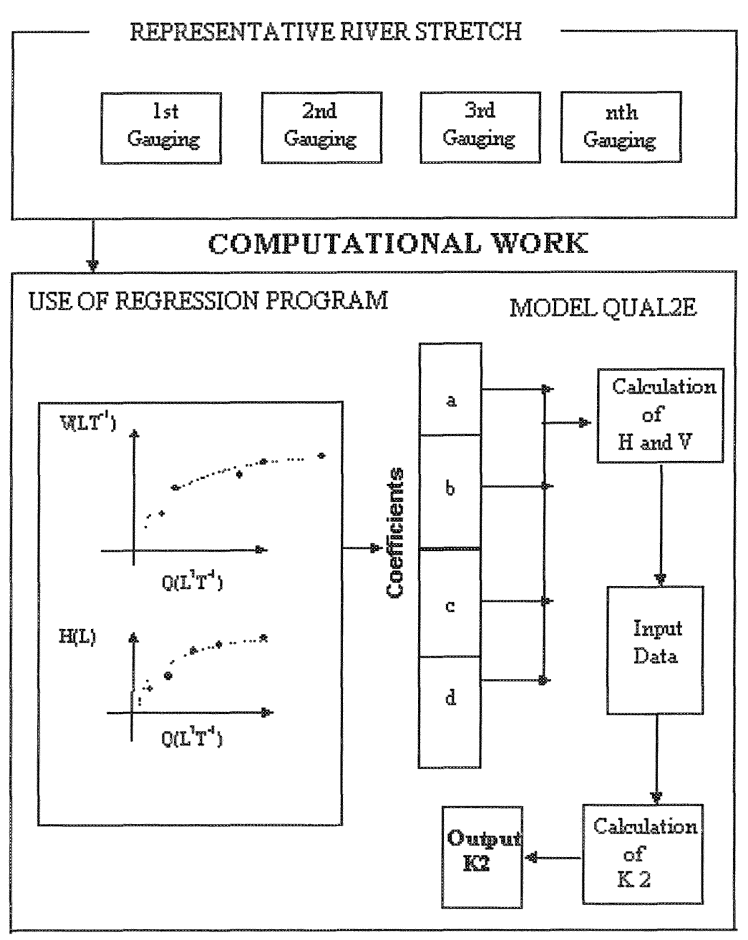

Figure 10.1 Method stages - schematic flowchart(Siqueira and Cunha, 1997)

\subsection{Conclusion}

Three field quantification methodologies for $K_{2}$ are discussed, the tracer technique being currently the most widely accepted. When the financial, technical and human resources conditions are insufficient for tracer testing, the re-aeration coefficient has to be obtained by predictive equations from literature.

A simple methodology for quantifying re-aeration, $K_{2}$ has been described for application to QUAL2E. For proper re-aeration coefficient determination in a given river stretch using the QUAL 2E model empirical and semi-empirical equations, at least three field measurements are required at different conditions of flow rate, followed by statistical data analysis.

Finally, until more detailed studies are conducted determining self purification in streams subject to waste water dumping, the proposed methodology appears to be a viable alternative for determining environmental impacts in flowing waters. 


\section{References}

Barbosa Jr., A.R. 1989. Desenvolvimento de metodologia para determinação do coeficiente de reaeração dos escoamentos naturais da água com o emprego de traçador gasoso. São Carlos. 187p. Master of Science Thesis. SHS - Escola de Engenharia de São Carlos, Universidade de São Paulo.

Barbosa Jr., A.R.; Giorgetti, M.F. 1995. Reaeração de Corpos de Água Naturais - Uma Metodologia para Quantificação com o Uso de Traçadores. In: 180 Congresso Brasileiro de Engenharia Sanitária e Ambiental, Salvador, Bahia, 17 a 18 set. Anais.

Barnwell Jr., T.O.; Brown, L.C.; Marek, W. 1989. Application Of Expert Systems Technology In Water Quality Modeling. Water Science and Technology, V.21, P.1045-56.

Bennett, J.P.; Rathbun, R.E. 1972. Re-Aeration in Open Channel Flow. U.S. Geological Survey Professional Paper 737.

Bicudo, J.R.; James, A. 1989. Measurement of Re-Aeration In Streams: Comparison of Techniques. Journal of Environmental Engineering, V.115, N.5, P.992-1010, Out.

Bittencourt, A.G.; Pereira, C.A.A.O.; Oliveira, L.H.W.; Nogueira, W.J.; Torsani; Loramie, R.L.; Mercer, G.W. 1995. Modelagem Matemática Do Rio Tietê Com Modelo Qual2eu Para Preparação Do Projeto Tietê. In: 18o Congresso Brasileiro De Engenharia Sanitária E Ambiental, Salvador, Bahia, 17-18 Set. Anais.

Bowie, L.G.; Mills, W.B.; Porcella, D.B.; Campell, C.L.; Pagenkopf, J.R.; Rupp, G.L.; Johnson, K.M.; Chan, P.W.H.; Gherini, S.A. 1985. Rates, Constants, and Kinetics Formulations In Surface Water Quality Modeling. Athens, Georgia, EPA.

Brown, L.C.; Barnwell, T.O. 1987. The Enhanced Stream Water Quality Models Qual2e and Qual2e-Uncas: Documentation and User Manual. Athens, Georgia.

Churchill, M.A.; Elmore, H.L.; Buckingham, R.A. 1962. The Prediction of Stream Reaeration Rates. Journal of the Sanitary Engineering Division.

Cubillo, F.; Rodriguez, B.; Barnwell Jr., T.O. 1992. A System for Control of River Water Quality for The Community of Madrid Using Qual2e. Water Science and Technology, V.26, N.7-8, P.1867-73.

Demetracopoulos, A.C.; Stefan, H.G.(A). 1983. Model of the Missisippi River Pool: Dissolved Oxygen. Journal of Environmental Engineering, V.109, N.5, P.1020-33.

Gastaldini, M.C.C. 1982. Análise Do Mecanismo De Autodepuração Do Rio JacaréGuaçú Através De Modelo De Qualidade De Água. São Carlos, S.P. Master of Science Thesis - Escola De Engenharia De São Carlos, Universidade De São Paulo.

Giorgetti, M.F. 1991. Natural Re-Oxygenation of Streams - Methodologies for The Measurement of Re-Aeration Coefficients. / Apresentado Ao International Workshop On River/Reservoir Approach To Watershed Management -. Environmental Aspects, São Carlos.

Koh, H.L.;Lim, Poh.E.; Lee,H.L.. 1995. Water Quality Modelling for An Estyary In Johore. Water Pollution Research Journal of Canada. V.30, N.1.

Langbein, W.B.; Durum, W.H. 1967. The Aeration Capacity of Streams. U.S. Geological Survey Circular n.542. 
Lo, K.S.L.; Chen, H.H. 1991. Water Quality Management of Keelung River, Northern Taiwan. Water Science and Technology, V.24, N.6, P.109-16.

Moog, D.B.;Jirka, G.H.. 1999b. Air-Water Gas Transfer In Uniform Channel Flow. Journal of Hydraulic Engineering, V.125, N.1, P3-10.

Moog, D.B.;Jirka, G.H.. 1998. Analysis of Re-Aeration Equations Using Mean Multiplicative Error. Journal of Environmental Engineering, V.124, N.2, P104-10.

Moog, D.B.;Jirka, G.H. 1999a. Stream Re-Aeration In Nonuniform Flow: Macroroughness Enhancement. Journal of Hydraulic Engineering, V.125, N.1, P11-16.

O’Connor, D.J.; Dobbins, W.E. 1958. Mechanism of Reaeration in Natural Streams. ASCE Transactions, v.123, n.2934, p.641-684.

Owens, M.; Edwards, R.W.; Gibbs, J.W. 1964. Some Reaeration Studies in Streams. International Journal of Air and Water Pollution, v.8, n.819, p.469-486.

Qiasi,W.D.; Thibodeaux, L.J. 1997. Impact of Barge Traffic On Stream Re-Aeration: Laboratory Experiments. Journal of Environmental Engineering, V.123, N.7, P71620.

Rathbun, R.E. 1977. Re-Aeration Coefficients of Streams - State-of-The-Art. Journal of The Hydraulics Division, V.103, N.Hy4.

Schultz, H. E. 1990. Investigação do mecanismo de reoxigenação da água em escoamento e sua correlação com o nível de turbulência junto à superfície - II. São Carlos/SP. 865p. PhD. Thesis - Escola de Engenharia de São carlos, Universidade de São Paulo.

Siqueira, E. Q; Cunha, A.C. O 1997. Coeficiente de Reoxigenação no Modelo QUAL2E: Metodologia de Previsão. In: 19o Congresso Brasileiro de Engenharia Sanitária e Ambiental, Foz do Iguaçú, Paraná, 14 a 19 set. Anais.

Siqueira, E.Q. 1996. Aplicação Do Modelo De Qualidade De Água (Qual2e) Na Modelação De Oxigênio Dissolvido No Rio Meia Ponte (Go). São Carlos. 90p. Master of Science Thesis - Shs - Escola De Engenharia De São Carlos, Universidade De São Paulo.

Thibodeaux,L.;Poulin,M.;Even,S. A 1994. Model for Enhanced Aeration of Streams By Motor Vessels With Aplication To The Seine River. Journal of Hazardous Materials, V.37, N.3, P459-73.

Thomann, R. V.; Mueller, J. A. 1987. Principles of Surface Water Quality Modelling and Control. New York, N.Y., Harper and Row. 643p.

Trackston, E.L.; Krenkel, P.A. 1969. Reaeration Prediction in Natural Streams. Journal of the Sanitary Engineering Division, ASCE, v.95, n.SA1, p.65-94.

Tsivoglou, E.C.; Wallance, J.R. 1972. Characterization of Stream Reaeration Capacity. U.S. Environmental Protection Agency, Washington, D.C., Report n.EPA-R3-72012.

Walton, R.; Webb, M.1994. Qual2e Simulations of Pulse Loads. Journal of Environmental Engineering, V.120, N.5, P1017-31.

Weiss, P.T.. 1997. In-Stream Hollow-Fiber Membrane Aeration. Journal of Hydraulic Engineering, V.123, N.7, P716-20. 